\title{
The 2015 Election News Coverage: Beyond the Populism Paradox, the Intrinsic Negativity of Political Campaigns in Portugal
}

\author{
Susana Salgado
}

\section{INTRODUCTION}

Following the 2011 bailout and the implementation of severe austerity measures, the 2015 election was seen as an important test both to the mainstream political establishment and to the support for the country's European Union (EU) membership. The election result briefly plunged the country into uncertainty due to the incumbent right-wing coalition's very thin victory (36.86 per cent of the votes and 102 members of parliament (MPs) with no absolute majority in parliament). However, a quick reaction from five parties that had not won the election, but that held together a majority in parliament, allowed the formation of an alternative government solution. The unprecedented alternative solution was a socialist government supported by a parliamentary agreement with the leftwing political parties represented in parliament.

This research looks into how the election campaign, which preceded these political negotiations and took place after the bailout and its ensuing

\footnotetext{
S. Salgado $(\square)$

Institute of Social Sciences, University of Lisbon, Lisbon, Portugal

(C) The Author(s) 2019

S. Salgado (ed.), Mediated Campaigns and Populism in Europe, Political Campaigning and Communication, https://doi.org/10.1007/978-3-319-98563-3_4
} 
austerity, was portrayed in the news media. This was a challenging moment for Portuguese politics, with strong potential for further polarization and for the emergence of populist actors and ideas. Populism is often perceived as a reaction to crisis (e.g. Mudde 2004; Taggart 2004; Kriesi 2014), and, at the time, in Portugal, there was not only disillusion with elites and political representation but also great economic uncertainty. Given that the news media can play an important role either in underpinning or in counteracting populism, this study of the news coverage of the 2015 election campaign will hopefully contribute to the further understanding of the relationship between mainstream media and populism.

The chapter describes the context of the 2015 election and provides background information on the country's political and media systems. It also explains the sample, which includes different types of news media outlets: printed newspapers, prime-time television news programmes, and digital-only news publications; centre-right and centre-left leaning outlets; as well as private/commercial and public service news media outlets. The data analysis that follows is, whenever possible, contextualized with previous research on elections and media in Portugal. The analysis addresses several features in the news coverage that are believed to impact on politics: political actors' media exposure and journalistic genres, interpretive journalism, news framing and coverage of issues, negativity, and populism. Special attention was given to the prevalence of the Euro Crisis in the news coverage of the campaign and in the political candidates' campaign messages.

\section{Context of the 2015 National Election}

The 2015 national election in Portugal was unique in many aspects. It was the first election after the implementation of a severe austerity programme that started in 2011 , which was contingent to the 78 billion euro bailout funds lent by international creditors. This programme ended successfully in May 2014 with the country's economy finally showing some signs of improvement, which very likely benefited the incumbent coalition (PàFPortugal à Frente, in English Portugal Ahead), first in several opinion polls carried out during the campaign and then in the election results. The incumbent coalition led by former Prime Minister Pedro Passos Coelho, was formed by the two same parties that had ruled the country in coalition from 2011 to 2015: the Social Democratic Party (PSD) and the Democratic and Social Centre-People's Party (CDS-PP). The coalition 
won the election, but its result was not enough to maintain the absolute majority it had previously in Parliament (PSD and CDS-PP had nearly 51 per cent of the votes in the 2011 election).

The 2015 election results caused a deadlock and almost a political crisis in the days that followed the election. The Socialist Party (PS) leader, António Costa, had always ruled out the possibility of any coalition with PSD and CDS-PP claiming fundamental differences. The new minority government led by Pedro Passos Coelho could not find parliamentary support, whilst the votes for all of the left-wing parties were reinforced in 2015. The centre-left PS recovered from 28 per cent in 2011 to 32 per cent in 2015, but could not form a stable government on its own. CDU (Unitary Democratic Coalition-an electoral alliance between the Communist Party (PCP) and the Green Party (PEV) led by the communists' leader Jerónimo de Sousa) and the left-wing BE (Left Block) also increased their votes: from 7.91 to 8.25 per cent in the case of CDU, and particularly BE, from 5.17 to 10.19 per cent almost doubled its voting.

Even though these results confirm the idea that many Southern Europe voters turned preferably to the left after the implementation of the austerity programmes, they also highlight important differences between Portugal and Spain and especially Greece. All in all, Portuguese mainstream parties were still able to secure more than 70 per cent of the votes in 2015, and Portugal is a rare case of a bailed-out country re-electing the government that was responsible for implementing the austerity measures.

Despite of the frailties of a minority government resulting from the PàF coalition, Prime Minister Pedro Passos Coelho was sworn by the then President Aníbal Cavaco Silva to form government. This government only lasted 11 days, because the left-wing parties (the majority in parliament), together with PAN's (party "People, Animals and Nature") representative, totalling $123 \mathrm{MPs}$, voted a motion to reject the PàF government programme, when this was presented in parliament. This was the first time in the history of Portuguese democracy that an elected and appointed government fell immediately through a rejection of its programme in Parliament. It was also the first time that PCP, PEV, and BE jointly supported the socialists to provide an alternative government solution with the objective of preventing a second PSD/CDS-PP coalition government.

The new parliamentary configuration that resulted from the 2015 election and the rejection of the PàF coalition government programme has 
thus created an unprecedented situation in Portugal: the coalition that won the election could not actually rule. The president finally had to appoint the PS leader, António Costa, to form another government, one that had guaranteed parliamentary approval, and a new government was sworn in. The left-wing parties' agreement became known as the "geringonça", after derogatory comments by the then CDS-PP leader, Paulo Portas. There is no exact translation of the term "geringonça" into English language, but basically it means a flawed contraption, a ramshackle coalition.

The state of the economy and the consequences of the austerity measures were important issues in the campaign. In its first years, the government led by Pedro Passos Coelho implemented state spending cuts and an overall increase of taxes, but started to ease these measures as the election year was approaching, and during the electoral campaign both PSD and CDS-PP (the two parties in the PàF coalition) argued that Portugal was finally recovering from economic recession and low market credibility due to the reforms that had been implemented by their government. For its part, the Socialist Party, led by António Costa, campaigned against the austerity measures and on the promise of easing immediately the most painful measures and reverting the PSD/CDS-PP government reforms over time.

Most of these measures were part of the bailout memorandum of understanding, but Pedro Passos Coelho decided to go beyond the agreement the country signed with the international creditors (European Commission, European Central Bank, and the International Monetary Fund) and implemented even harsher measures in some cases. Given the sacrifices that adopting the Euro had already entailed for Portuguese citizens, the 2015 election was therefore not only a test for these political parties, but to some extent also for the EU membership and the idea of further EU integration.

A parliamentary election taking place after major economic and financial crises can also be considered a barometer of the level of satisfaction with the way democracy is working in general, especially in a country where turnout has been declining sharply over the years. In fact, turnout in parliamentary elections has been decreasing in Portugal since the first democratic election took place in 1975 , when it was 91.5 per cent. In 2015 , was only 55.9 per cent and in the previous election, in 2011 , had been 58.1 per cent. 


\section{Portuguese Political and Media Systems}

Portugal is a semi-presidential political system, in which a government led by a prime minister (usually the leader of the most voted-for party in parliamentary elections) coexists with a president elected directly by the people in presidential elections. The president appoints the prime minister, taking into account the parliamentary election results and after consulting all political parties with parliamentary representation. The president has the power to dissolve the parliament in extreme crisis situations.

Portugal's parliament has a single chamber of 230 members with a four-year mandate. MPs are elected through electoral constituencies (18 administrative districts, plus the autonomous regions, Azores and Madeira, and 2 others for Portuguese citizens residing abroad, in European countries, and in the rest of the world), but after being elected MPs represent the entire country. To be able to rule with the support of a majority in parliamentary, a party (or coalition) needs to secure at least 116 seats. The representation of political parties in parliament after the 2015 national election included the two largest parties, one centre-right (PSD) and one centre-left (PS); a right-wing conservative party (CDS-PP); three leftwing parties (BE, PCP, and PEV); and the first-timer party PAN.

Mainstream politicians and journalists maintain close ties in Portugal; and given that investigative journalism has become more and more rare mainly due to the lack of resources, journalists overly rely on politicians as sources of information (e.g. Mesquita 2003; Salgado 2010). Overall, the media agenda is what journalists think is the audience demand, news values, but it also takes into account the political agenda and occasional partisan political pressures. The government, the president, and the parties with the most votes (PSD and PS) have a stronger negotiating power with the news media and usually they also receive more media coverage (Salgado 2007), which means that they are strong influences on how issues and political developments are interpreted and framed in the news. It is also common to see journalists accepting invitations to work with politicians, and many mainstream politicians are regular commentators in news media outlets. It was, for example, the case of the current President Marcelo Rebelo de Sousa, who became well known to the public due to his regular commentaries in prime-time television since the 1990s (for more details on this case, see Salgado 2018a). All of this results in mainstream journalists being often perceived as belonging to the elite and being in fact too close to the political class. 
Despite of these close links, Portuguese news media outlets do not express directly their party preferences (a noteworthy exception is the daily newspaper Correio da Manbã that has occasionally endorsed local elections candidates) and their ownership is independent from political parties. This is explained by specific media legislation that was prepared in the aftermath of the 1974 revolution to ensure media independence, but it is also part of a commercial strategy by news outlets to not drive readers/viewers away. Nevertheless, it is often possible to detect partisan bias in news content through the salience that is attributed to certain issues, events, and actors; the commentators who are selected to contextualize and interpret current events; and in opinion articles, which can potentially affect the public's political perceptions.

Despite the growing importance of the Internet for access to news, particularly among the younger generations (Mitchell et al. 2018), television is still the main source of political information for most citizens in Portugal (Newman et al. 2016; Salgado 2018a). Throughout history, television has actually been a reflection of the political regime, and politicians have always tried to use it to their advantage. The objectives have varied from, for example, using television as an instrument to shape public opinion and mobilize supporters, as entertainment to distract public attention from problematic issues, or as a tool to campaign against and attack opponents.

The climate of political confrontation that followed the April 25th democratic revolution in 1974 has deeply influenced the media system: ideological competition replaced the old regime's censorship, but paved the way to an explosion of politically biased publications, which transformed journalism in Portugal and promoted a greater diversity of media outlets and more plurality of information. However, at the time, as Mesquita (1994) explains, more than informing about facts, news media outlets mainly conveyed political propaganda and ideology from political parties and interest groups. This explains why one of major concerns in the postrevolution period was to provide legislation in support of the liberation of the media sector from the direct influence of political parties, in order to ensure not only independence and freedom, but also impartiality.

The wave of nationalizations in the media system in the 1970s that was initiated with the objective of controlling the media in the new context of freedom of opinion and expression was followed by the strong privatization of the sector from 1985 to 1995, which was decided by conservative governments. One of the most important changes in the media landscape 
was the licencing of two private commercial television channels (with open signal and national reach). Today, the Portuguese media system is regulated by specific laws, which include guidelines for plurality both in the media environment as a whole and in the media content of each news outlet, especially in the case of public service media. An independent regulatory body for the media (Entidade Reguladora para a Comunicação Social) was created to oversee the media activity and ensure that excesses are not committed.

The type and degree of influence of the State in the media system have varied according to the moment in history; but overall the State has always maintained an important presence in the media system, whether through the direct holding of the most important news media outlets or through a strict regulation of the sector. Currently, the State still owns two open signal national television channels, several radio stations and is a major shareholder in Lusa news agency. Private companies own the two remaining open signal national television channels, several radio stations and print news media, including some of the most influential in shaping public opinion, such as newspapers Expresso and Público.

For this reason, both Expresso and Público were included in the sample selected for this study. Due to its increasingly important readership levels, the online and daily version of Expresso was coded, as well as two other papers that are published only online, Observador and Noticias ao Minuto. These online news media outlets were considered the most relevant for national politics at the time this sample was selected. Taking into account levels of readership, the sample also included three printed daily newspapers, Público and Jornal de Noticias, and the tabloid Correio da Manhã. Regarding television, the research focused on the prime-time news programmes of RTPl, the most important public service television channel, and on the two private television channels, SIC and TVI. These three television channels have national reach and are transmitted in open signal.

\section{The News Coverage of the 2015 Election Campaign:}

\section{DATA ANALYSIS}

The content analysis of these nine news media outlets overall confirms the salience that politics has in the news coverage of current events in Portugal and more specifically the salience that journalists usually attribute to election campaigns. During the two weeks of official campaign, 1659 


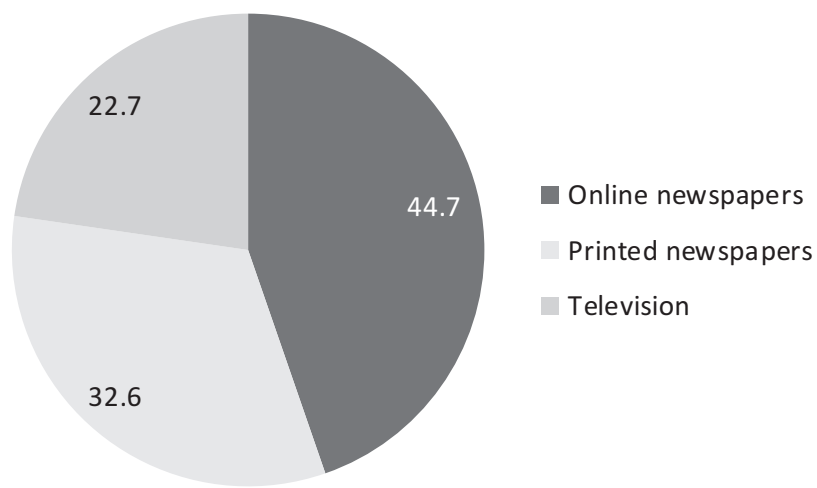

Fig. 4.1 News coverage of the 2015 election campaign per type of media (percentages)

election news stories were published and broadcast in these news media outlets (Fig. 4.1).

Almost half of these news stories (44.7 per cent) were published in the online newspapers, mainly in Notícias ao Minuto (20.4 per cent) and Expresso online (15.4 per cent), and slightly less in Observador (8.6 per cent). These results do seem to substantiate the assumption that the Internet has increased the amount of political information available (e.g. Graber and Smith 2006). The remaining news stories were published in the daily newspapers (32.6 per cent), in particular in Correio da Manhã (11.8 per cent) and Público (11.7 per cent), and slightly less in Jornal de Noticias (9.2 per cent); and broadcast on television (22.7 per cent), almost equally distributed among the three channels (SIC: 8 per cent; RTPl: 7.7 per cent; TVI: 7.3 per cent). Open signal television news programmes tend to cover electoral campaigns very similarly during the official campaign period, showing an overview of the candidates' daily campaign initiatives and statements (Salgado 2007, 2010).

The election campaign was mostly reported through news stories (73.9 per cent). The remaining genres were less frequent in the news coverage; however, it should be noted that opinion articles (12.1 per cent), reportage $(6$ per cent), and television live broadcast pieces ( 5.7 per cent) also had a noteworthy relevance. The journalistic genre in which more negativity was found was opinion: 62 per cent of the opinion articles on the campaign were coded as conveying mostly a negative tone; however, the 
prevalence of negativity in plain news stories was also considerable: 40.9 per cent. Negativity here includes both negative tone and conflict, which can be initiated by the candidates (e.g. negative campaigning, attacks on opponents that are simply reported in the news) or by the news media and journalists (negative assessments and interpretations of the candidates, the election campaign, or of politics in general).

Substantial differences in the selection of journalistic genres with which to cover the competing political parties and their leaders usually mean that journalists introduce some implicit differentiation between parties in the news coverage, which in itself hints voters of the varying importance of each party and candidate. For example, opting for an interview, reportage, or a live coverage of a party's campaign requires more resources and time/ space and indicates that journalists are attaching a greater importance to that political party and/or party leader, especially if the journalistic treatment is not exactly the same for all parties and leaders. This is a form of underlying journalistic interpretation that is fulfilled by the selection of news formats and includes hints on how to perceive political reality (Salgado 2014: 281-282); in this case, the election campaign and the chances of success of the different political parties in the election. Journalistic genres may thus be a way of indirectly informing voters about the different degree of political importance and eligibility of candidates and parties.

\section{Sources of Information and Personalization}

The political parties and candidates with more chances of winning or achieving a good result in the election (considering previous election results and opinion polls) motivated more opinion articles, reportages, interviews, and television live coverage. These were the PSD and PS, and their leaders, António Costa and Pedro Passos Coelho. Parties already represented in parliament, such as CDS-PP, PCP, and BE, followed in terms of overall media exposure and salience. PàF (the incumbent coalition, PSD and CDS-PP) and PSD had more news media attention, in terms of amount of news stories; however, the PS and its leader António Costa motivated more opinion articles and more live broadcasts than the incumbent coalition (PàF) and its leader Pedro Passos Coelho. It is also interesting to note that Pedro Passos Coelho completely outshined his coalition partner Paulo Portas and the same happened with their parties, PSD and CDS-PP. 
Regarding the levels of personalization in the election news coverage, 65.9 per cent of all news pieces focused on the party leaders, as the main political actor. However, it is important to note that the parties' campaign is usually organized taking into account the media coverage and party leaders usually take on the leading role in conveying the party messages and in leading the campaign initiatives. Directly linked to personalization are the levels of the party leaders' depiction and the insertion of their direct quotations in the news coverage, that in this case were only slightly lower than the news story focus, 62.3 and 60.2 per cent, respectively. Party leaders were also the main source of information for journalists covering the campaign, 58.6 per cent; while other party members were considered only in 17.2 per cent of the news coverage. The third and fourth most important sources of information for journalists were experts (8.7 per cent), a group that includes political pundits and economists, for example, and opinion polls (6.8 per cent). Citizens were included in 3.8 per cent of the election news.

Although usually high, the levels of personalization in the news coverage are not exactly the same for all political parties. The PS leader, António Costa, had more news coverage (17.1 per cent) than his party (5.1 per cent). Conversely, Pedro Passos Coelho motivated slightly less news coverage focused on him (16.1 per cent), but his coalition motivated more news stories (10.14 per cent) than PS. António Costa had thus slightly more coverage than the incumbent prime minister (Pedro Passos Coelho), but his level of personalization in the news was also higher in general, showing that overall the media outlets were more interested in the leader than in the party, and/or that, at the time, António Costa's political capital was higher than that of his own party, at least from the journalists' point of view.

The political leaders' personal characteristics were also present in the news coverage of the 2015 election campaign. The simple mention or the discussion of personal characteristics, such as competence, leadership, credibility and trustworthiness, morality and truthfulness, rhetorical skills, physical appearance, ideological stances, charisma, or aspects of the candidates' personal life were found in 30.1 per cent of the news items. The most recurrent personal characteristic was credibility (15.7 per cent), which is likely related to the simultaneous political scandals in which allegations of corruption involved prominent national political figures, including the former socialist Prime Minister José Sócrates. The candidates' ideological stance ( 4.3 per cent), competence ( 3.6 per cent), and truthfulness $(2.6$ per cent) were less discussed in the news media. 
When journalists referred to the candidates' personal features, they focused mainly on the PS leader, António Costa (105 news items), and on the leader of the incumbent coalition, Pedro Passos Coelho (92 news items). Catarina Martins, the Left Block (BE) coordinator, and Jerónimo de Sousa, the communists' leader, had 55 and 47 news items, respectively, including these elements. In all of them, the personal characteristic that was most discussed by journalists was "credibility".

\section{Issues and Euro Crisis in the Election Campaign}

If, as Cohen (1963), we consider that the news media are "successful in telling the people what to think about", we assume that Portuguese citizens made their voting decisions mostly having the state of the country's economy in their minds. This issue has recurrently been a concern for most families over the past few years and became even more relevant with the 2011 bailout and the ensuing austerity (cuts in salaries and pensions, and strong decrease in the public investment in health, education, social security, etc.).

Looking at the data closer, it is possible to observe that, although these issues were included in most of the political parties' campaigns, journalists themselves have also introduced these topics in the agenda and in the campaign news coverage, for example, through comparisons of the different political parties' proposals on economic issues or covering the consequences of austerity (news focusing on "social affairs" represented 11.6 per cent of the election news coverage). Nearly 40 per cent of the news coverage referred to the state of the economy, and addressed topics such as the country's external financial dependence, the international creditors and financial markets, and the measures that should be implemented to stimulate economic growth and reduce unemployment. Given that the state of the economy has been recurrently a key issue in election campaigns in Portugal (e.g. Salgado 2009) and this was the first election after the 2011 bailout, the interest in this topic is not surprising.

The Euro Crisis was thus also a strong topic in the election campaign; it was included in 25.2 per cent of the news coverage. Most of these news items dealt with the austerity measures and their consequences (15.9 per cent); but they also referred to the consequences of the single currency for the Portuguese economy, to the sustainability of the country's debt and its impact on economic growth, to the speculation against the countries with 
sovereign debt problems and the euro in general, or to the future of the single currency and of the EU. Overall, online news media outlets addressed the Euro Crisis issue more often (30 per cent) than printed newspapers (24.9 per cent) and television (18.7 per cent).

In absolute terms, the Euro Crisis was introduced in the election campaign (and thus reflected in the news coverage) mainly through the two largest political parties (PSD and PS) and their leaders (Pedro Passos Coelho and António Costa). However, it is important to note that proportionally other parties and candidates made a greater effort to discuss the Euro Crisis and its consequences, especially the leaders of fringe leftwing parties, such as Garcia Pereira (PCTP / MRPP — Portuguese Workers' Communist Party/Reorganizing Movement of the Party of the Proletariat), and Rui Tavares (Livre/TDA-Free/Time to Move Forward), who had 60 and 42 per cent of their news coverage focused on this issue, respectively.

The two other issues that received the most news media coverage were party politics (13.3 per cent) that includes topics related with the political parties' strategy, intra-party competition and conflict, or the parties' internal organization; and opinion polls (10.3 per cent), which refers to news that report the opinion polls results, but also to news stories that were focused on opinion polls as an issue, that is, discussions about the effects of releasing opinion polls during the campaign and about the actual impact of opinion polls on the campaign and on the election outcome.

\section{News Framing of the Election Campaign}

Overall, issues were very important in the news framing of the 2015 election campaign: 57.4 per cent of the news coverage was mainly focused on issues (issue news framing), while the remaining 42.6 per cent were dominantly devoted to strategy (strategic news framing) (Table 4.1). Considering that literature suggests that there is a general prevalence of strategic news framing in the coverage of politics and elections in particular (Patterson 1993; Cappella and Jamieson 1997) and because this was a very competitive election, this result may seem surprising at first sight; however, it is not totally unexpected if we consider previous content analysis studies that focused on the coverage of politics in routine periods, and in which the Portuguese political news coverage was included in the group of countries with the least prevalence of "strategic game framing" (Aalberg et al. 2017). 
Table 4.1 Dominant news framing per type of media

\begin{tabular}{lccc}
\hline & \multicolumn{2}{c}{ Dominant framing of politics } & Total \\
\cline { 2 - 3 } & Strategic & Issue & \\
\hline Television & 159 & 218 & 377 \\
Printed newspapers & 242 & 299 & 541 \\
Online newspapers & 305 & 436 & 741 \\
Total & 706 & 953 & 1659 \\
\hline
\end{tabular}

Strategic news framing implies that politics is framed by journalists mostly as a game, a competition (also known as "horse race coverage"), in which the political actors' strategy is considered more newsworthy than their policy proposals. News items thus focus mainly on tactics and strategies for the campaign and the election, opinion polls, and on the candidates' motivations and personal features. Even though the strategic frame can also be used in the coverage of issues (e.g. Lawrence 2000), in this study the "issue frame" refers to the type of news coverage that is focused on issues and on the political actors' issue positions, and it can also include substantial information about social problems, such as official reports and statistics, for example.

The specific elements of strategic framing found in the 2015 election news coverage were mainly related to "strategy and tactics" and "winning and losing", which means references to politicians and parties' strategies for winning the election or for achieving political success in general, and direct references to winning or losing (e.g. elections, debates, and polls). The use of strategic news framing in the news coverage varies between 41 and 44 per cent in the three types of media considered in the sample (television, newspapers, and online papers), being just slightly more prevalent in newspapers, very likely due to the greater amount of analysis and opinion pieces.

Except in the case of the PS and its leader, António Costa, the coverage of all political actors (both political parties and political leaders) was more focused on issues than on strategy and tactics. Interestingly, this happened with the incumbent coalition (and most voted for) and the smaller parties, both the parties with parliamentary representation (BE, PCP, and PEV) and the fringe parties not represented in parliament. In the case of PS and its leader, a plausible explanation for the exception relates to the fact that they were the real challengers in this election, singled out in several opinion polls as the most likely winners of this election. 


\section{Negativity in the Media and in the Parties' Election Campaign}

Previous studies have concluded that the tone of the news media coverage of politics and elections in Portugal tends to be more negative than positive (Salgado 2010; Esser et al. 2017). Different reasons explain the prevalence of negativity in the Portuguese political news in the past years, among which is very close and competitive elections and high-profile national politicians involved in corruption scandals. But negativity can also stem from the coverage of controversies and conflict between political opponents, which is a common feature in the Portuguese journalists' way of reporting politics, as a "dialogue" between competitors (Salgado 2007, 2010).

The 2015 election confirmed this tendency. Most news items on the election had a neutral or negative tone (including conflict and failure) and very few were positive (i.e. focused on political success, and progress). The most negative were the online-only news media outlets, while the news coverage in television and newspapers was more neutral than negative, although with small differences (Table 4.2). News items with positive tone accounted only for 13 per cent of the entire news coverage. News items were coded as neutral when they did not contain any indicators of negative or positive tonality or when the presence of both tones was balanced. It is also important to note that the most negative journalistic genre was opinion: 62 per cent of this type of news items had mainly a negative tone, while only 2.5 per cent were positive.

Negativity has been often linked to an interpretive style of political journalism (for more details on extant literature and main arguments, see Salgado and Strömbäck 2012). This was confirmed in the Portuguese case: the prevalence of journalistic interpretation was slightly higher in news items that were coded as having a negative tone, 34.3 per cent,

Table 4.2 Tone of coverage per type of media

\begin{tabular}{lcccr}
\hline & \multicolumn{3}{c}{ Tone } & \multirow{2}{*}{ Total } \\
\cline { 2 - 4 } & Negative & Nentral & Positive & \\
\hline Television & 134 & 196 & 47 & 377 \\
Printed newspapers & 230 & 255 & 56 & 541 \\
Online newspapers & 324 & 302 & 115 & 741 \\
Total & 688 & 753 & 218 & 1659 \\
\hline
\end{tabular}


compared to 31.6 and 29.7 per cent in positive and neutral news items, respectively. Although further studies and content analysis would be necessary to confirm this trend over time, it seems quite plausible to relate the absence of journalistic interpretation with neutral news coverage.

\section{Interpretive Journalism in the Election News Coverage}

Following Salgado and Strömbäck's (2012) proposal on how to conceptualize and operationalize interpretive journalism, the present analysis ascertained the presence of three different types of interpretive journalism in the election news coverage: journalistic explanations, journalistic speculations, and journalistic overt commentary. More specifically, "journalistic explanations" refer to explanations included in the piece without any support by verifiable facts and news sources, which may, for example, aim at explaining the reasons behind events (retrospective speculations) or explanations about what was meant by a politician's statement; “journalistic speculations" about the future include potential future consequences of events and statements; and "journalistic overt commentary" refers, for example, to the inclusion of non-neutral expressions of opinion by the journalist who is covering the story, which cannot be supported by verifiable facts (Salgado and Strömbäck 2012).

The overall prevalence of interpretive journalism in the 2015 election news coverage was 31 per cent. It was slightly higher than the results obtained in previous studies that found values between 15 and 20 per cent (Salgado 2010; Salgado et al. 2017). The fact that this was a very competitive election happening during a particularly challenging context might help to explain why journalists felt the need to provide more interpretation, or used the opportunity to expand their own influence on politics.

In the 2015 election news coverage, interpretive journalism was overall more common in television ( 35.5 per cent); but the difference between the prevalence of journalistic interpretations in television and in the other types of media is not pronounced: 32.1 per cent of the coverage in newspapers was coded as having some kind of journalistic interpretation (explanations, speculations or commentaries) and in online papers, the percentage was 29.8.

Regarding journalistic genres, journalistic interpretation was, as expected, virtually always present in commentary and opinion by journalists and editorials, but it was also very common in reportages (71.7 per cent) and in televised live coverage (35.7 per cent). And most importantly, 
Table 4.3 Prevalence of interpretive journalism per type of news item

\begin{tabular}{lrrr}
\hline & \multicolumn{2}{c}{ Interpretive Journalism } & Total \\
\cline { 2 - 3 } & No & Yes & \\
\hline News story & 1013 & 213 & 1226 \\
Reportage & 28 & 71 & 99 \\
Opinion & 2 & 198 & 200 \\
Portrait & 5 & 6 & 11 \\
Interview & 6 & 5 & 11 \\
TV live broadcast & 61 & 34 & 95 \\
Other & 15 & 2 & 17 \\
Total & 1130 & 529 & 1659
\end{tabular}

the prevalence of journalistic interpretation in plain news stories was 17.3 per cent (Table 4.3). This is important because in news stories, the presence of interpretations and opinions by journalists is not signalled.

\section{Populism in the Election Campaign and in the Media}

It is not uncommon to see candidates toughening their rhetoric and resorting to populism in election campaigns, as these are periods of intense political debate and competition, in which political communication is thoroughly staged to convince voters and to induce media coverage. In spite of this, and even though there is reference to conflict in 53 per cent of the news coverage and 42 per cent of the news items were coded as having predominantly a negative tone, the results of the content analysis do not point to high prevalence of populism in the 2015 election campaign, as it was covered by the news media.

In fact, the analysis revealed the almost complete absence of populist features of political communication in the news media coverage. The few exceptions are the very scarce news stories that covered the campaign initiatives of populist parties, such as the extreme right National Renewal Party (PNR), which is inspired by the French Front National, and the Democratic Republican Party (PDR), a newly created centre-left party, led by António Marinho e Pinto.

Although expanding its importance throughout Europe, right-wing populism has been virtually absent in Portugal. The far right populist PNR has grown only marginally in recent years, it had 0.50 per cent of the votes in the 2015 election (it had had 0.32 per cent in $2011,0.2$ per cent in 
2009, and 0.16 per cent in 2005). António Marinho e Pinto illustrates a very different type of populism. This politician was elected in the 2014 European Parliament Election with an anti-elite and anti-establishment populist discourse focused on the need to change the political system, in order to root out corruption. He presented himself as belonging to the people and as someone who understood the needs of the people, unlike the other candidates. In the 2014 European Parliament election, António Marinho e Pinto ran as the head of the Earth Party (MPT) list, but after disagreements with the MPT party leader, he decided to create his own political party (PDR) just before the 2015 election. However, a number of internal strives, political scandals, and even criminal issues involving other PDR members affected the party credibility and its campaign performance, and the first PDR electoral result did not go beyond 1.14 per cent (António Marinho e Pinto's result with MPT in the European election was 7.14 per cent).

The content analysis looked for the expression of specific features of populism that had already been identified in extant theoretical literature and in previous empirical research (e.g. Canovan 1999; Taggart 2000; Jagers and Walgrave 2007), namely "references to the people", distinction between "us and them", exclusion through the identification of one or several "out-groups" (e.g. immigrants or religious and ethnic minorities), anti-elitist stance in politics, anti-system positioning, and the notion of an idealized nation.

The analysis of the 2015 election news coverage has shown that politicians used the expression "the people" to address voters in approximately 6 per cent of their statements. Of all the features of populist political discourse, the use of the expression "the people" was by far the most common in Portugal. And although its use was more common in the PCP, which was mainly a synonym for working class and proletariat, it is not an intrinsic characteristic of political party discourse during the election campaign. The resort to this rhetorical strategy in PCP's case does not entail an (ideal) homogeneity of the people or the denial of the legitimacy of political opponents, and therefore it does not reject the social and political legitimacy of different groups and interests within what is considered "the people", which is an inherent characteristic of populism. The resort to the word "people" was instead mainly a rhetorical strategy employed by some party leaders to engage voters in their speeches and to address their political constituencies directly, especially when these are mainly composed of the most disadvantaged social classes (Table 4.4). 
Table 4.4 Populism-References to "the people"

\begin{tabular}{|c|c|c|c|}
\hline \multirow{2}{*}{$\begin{array}{l}\text { Political actors (parties and } \\
\text { leaders) }\end{array}$} & \multicolumn{2}{|c|}{ Populism-People } & \multirow{2}{*}{$\begin{array}{l}\text { Percentage of references to the } \\
\text { people in each party and party } \\
\text { leader discourse }\end{array}$} \\
\hline & No & Yes & \\
\hline PàF (Portugal Ahead coalition) & 157 & 4 & 2.48 \\
\hline PS (Socialist Party) & 81 & 4 & 4.70 \\
\hline $\begin{array}{l}\text { PPM (People's Monarchist } \\
\text { Party) }\end{array}$ & 3 & 2 & 40 \\
\hline $\begin{array}{l}\text { PDR (Democratic Republican } \\
\text { Party) }\end{array}$ & 0 & 1 & 100 \\
\hline $\begin{array}{l}\text { Juntos pelo Povo (Together for } \\
\text { the People) }\end{array}$ & 3 & 1 & 25 \\
\hline MPT (Earth Party) & 7 & 1 & 12.5 \\
\hline PNR (National Renewal Party) & 0 & 2 & 100 \\
\hline $\begin{array}{l}\text { Pedro Passos Coelho (PàF } \\
\text { coalition leader) }\end{array}$ & 261 & 6 & 2.24 \\
\hline Paulo Portas (CDS-PP leader) & 58 & 3 & 4.91 \\
\hline António Costa (PS leader) & 266 & 18 & 6.33 \\
\hline $\begin{array}{l}\text { Jerónimo de Sousa (PCP- } \\
\text { Communist Party leader) }\end{array}$ & 117 & 44 & 27.32 \\
\hline $\begin{array}{l}\text { Catarina Martins (BE-Left } \\
\text { Block leader) }\end{array}$ & 153 & 1 & 0.64 \\
\hline $\begin{array}{l}\text { António Marinho e Pinto (PDR } \\
\text { leader) }\end{array}$ & 42 & 8 & 16 \\
\hline $\begin{array}{l}\text { Joana Amaral Dias (movement } \\
\text { We the Citizens) }\end{array}$ & 8 & 5 & 38.46 \\
\hline Rui Tavares (LIVRE party) & 18 & 1 & 5.26 \\
\hline
\end{tabular}

Legend: The table presents the results in terms of absolute coverage of each party/party leader; the results were not weighted taking into account their different media exposure

The prevalence of the "us and them" argumentation in the election news coverage was 2 per cent. The identification of what was meant by "them" in these cases revealed that "them" referred mainly to international creditors (EU institutions, International Monetary Fund, etc.) and to the political parties that have been ruling the country since the 1974 democratic revolution (PS, PSD, and CDS-PP). Here too, it was PCP that mostly used this type of argumentation in the election campaign.

Directly related to this, is the anti-elitism positioning, which was found in 5.4 per cent of the coverage: 3.5 per cent referring to European and economic elites and 1.9 per cent to the national political elite. The resort to "anti-elitism" rhetoric was more scattered: it was found in several 
left-wing parties, including PCP and the Left Block (BE), but also in even smaller, fringe parties. Anti-system views of politics were only found in 1.9 per cent of the election news, and mainly through the fringe political parties, not represented in parliament, that were asking for deep political system reforms. Overall, this result also suggests a rather considerable cross-party consensus over the political system as it stands.

Similarly, mentions to an "ideal nation" were present in 1.9 per cent of the campaign news coverage. And references to "out-groups" were even less: 0.6 per cent: these were mainly references to immigrants in general and 0.1 per cent to a religious minority (Muslims by the far right PNR). Portuguese society is accustomed to both emigration and immigration. Nearly 22 per cent of Portuguese citizens lived abroad in 2017 (Cordeiro 2017) and many immigrants from the former African colonies (Cape Verde, Angola, Guinea-Bissau, Sao Tome and Principe, Mozambique), Brazil, China, but also from other European countries live currently in Portugal.

Adding other elements of populist discourse to the analysis, the prevalence of populism in the news coverage was 5.7 per cent. These elements are mostly related to a "popularist" approach to politics, in the sense of politicians adjusting their messages to the understandings and preferences of the majority of the population, and include, for example, oversimplifications of issues, and the use of strategies, such as dichotomous approaches to issues and scapegoating.

It is interesting to note that the news excerpts coded as containing populism were direct or indirect citations of the politicians' statements, which means that these news media outlets apparently do not engage in populism themselves directly (i.e. media populism; for further information on this concept, see e.g. Mazzoleni 2003, 2014; Moffitt 2016). In the cases under study in this approach, the news media merely covered and replicated the politicians' messages. It is also important to highlight that hitherto news media outlets in Portugal seldom and only very reluctantly cover the campaign initiatives of the extreme right-wing PNR (National Renewal Party).

\section{CONCLUSION}

The low levels of populism in the election news media coverage are a reflection of the overall failure of populist political actors in Portugal. The 2015 election has put the political system resilience to test. However, 
despite the crisis and a trend towards the growth of different types of populism in Europe (including anti-establishment political actors-which could be particularly appealing in a country that had recently undergone a severe austerity programme), thus far there is in Portugal a persisting citizen support to mainstream parties, as the 2015 election results have shown. On the one hand, mainstream parties seem to have integrated in their political discourses and proposals much of what could be considered fuel for populism, and, on the other hand, the few populist political actors that have emerged in the political system have not been able to build a sufficiently coherent ideological alternative and to convince Portuguese voters.

Lack of charisma of its leaders (Marchi 2013) and the strong weight of a fascist political past (1926-1974) seem to be important obstacles to the success of extreme right parties, such as PNR (Salgado 2018b). António Marinho e Pinto did not, however, lack political charisma and although he positioned his party (PDR) at the centre of the party system and presented himself as someone who thinks and acts like the "people", he was not particularly fortunate in his party allegiances.

Left-wing populism also did not flourish in Portugal as it did in Spain with Podemos and in Greece with Syriza. Although the left-wing parties with parliamentary representation (BE, PCP, and PEV) combined result of 18.4 per cent in the 2015 election was their strongest record in the democratic period, it did not compare the most dramatic successes of Podemos or Syriza. In the case of Portugal, these left-wing parties were already integrated in the system and had previously occupied the political-ideological space that Podemos and Syriza took in their respective countries. The Portuguese government solution that placed the socialists governing with the parliamentary support of these three left-wing parties has also served to further integrate these left-wing parties into the political system.

The consistency of the political system averted the likely strong disruptions that were expected due to the hardship that Portugal had faced before the 2015 election and especially considering what had happened in other European countries in a similar situation. In Portugal, the political parties with parliamentary representation were successful in integrating divergence in their political discourses, which in turn prevented radical positions and the emergence of anti-system political stances.

Although there is no direct control over the media, the political system and the media system are very closely linked to each other. More than being adversaries, journalists tend to often cooperate with the political 
elite, and especially with the two most voted-for parties (PSD and PS). However, this does not mean that there is no space for a media agenda in election news coverage in Portugal. While a news coverage that is primarily issue-framed may at first suggest that journalists are merely reporting the candidates' proposals, the salience that was attributed to the economy and to the consequences of the Euro Crisis in this election campaign was, to a certain extent, promoted by journalists, and the level of journalistic interpretation has increased when compared to other periods in time. But, on the other hand, there are also cases of media's implicit support to certain political stances and political candidates by giving them more attention.

The news media usually select as most newsworthy the highest polling political candidates and the incumbent, especially if there are chances of re-election. This is a recurrent news pattern in election coverage in Portugal (see also Salgado 2007, 2010). However, it is interesting to note that, taking the distribution of votes into account and comparing the salience attributed to the two major political parties with that of the remaining parties, especially the ones with parliamentary representation, the latter tend to have proportionally more media exposure than they have electoral weight in the political system. This may have also contributed to prevent utmost polarization and more inflammatory political discourses.

Overall, the news coverage of the 2015 election campaign was mainly negative due to accusations between candidates and to the opinion and the journalistic interpretation present in the news. The coverage was also strongly personalized into the figure of the candidates competing for the prime minister position. These features of news coverage can be viewed as traces of the media's influence in the construction of election discourses and although other type of research approach would be necessary to evaluate the actual impact on electoral behaviour, this data analysis already provides important information regarding the significant role that the news media currently have in election campaigns.

\section{REFERENCES}

Aalberg, T., de Vreese, C., \& Strömbäck, J. (2017). Strategy and game framing. In C. de Vreese, F. Esser, \& D. Hopmann (Eds.), Comparing Political Journalism (pp. 33-49). New York and London: Routledge.

Canovan, M. (1999). Trust the people! Populism and the two faces of democracy. Political Studies, 47(1), 2-16. 
Cappella, J. A., \& Jamieson, K. H. (1997). Spiral of Cynicism. The Press and the Public Good. New York: Oxford University Press.

Cohen, B. (1963). The Press and Foreign Policy. Princeton, NJ: Princeton University Press.

Cordeiro, A. D. (2017, February 24). Portugal é o segundo país europeu com maior taxa de emigrantes. In daily newspaper Público. Retrieved from https:// www.publico.pt/2017/02/24/sociedade/noticia/emigracao-mantem-os-niveisaltos-da-crise-e-isso-e-devastador-para-o-pais-1763125.

Esser, F., Engesser, S., Matthes, J., \& Berganza, R. (2017). Negativity. In C. de Vreese, F. Esser, \& D. Hopmann (Eds.), Comparing Political Journalism (pp. 71-91). New York and London: Routledge.

Graber, D. A., \& Smith, J. M. (2006). Political communication faces the 21 st century. Journal of Communication, 55(3), 479-507.

Jagers, J., \& Walgrave, S. (2007). Populism as political communication style: An empirical study of political parties' discourse in Belgium. European Journal of Political Research, 46(3), 319-345.

Kriesi, H. (2014). The populist challenge. West European Politics, 37(2), 361-378.

Lawrence, R. (2000). Game-framing the issues: Tracking the strategy frame in public policy news. Political Communication, 17(2), 93-114.

Marchi, R. (2013). The extreme right in 21st century Portugal: The Partido Nacional Renovador. In R. Melzer \& S. Serafin (Eds.), Right-wing Extremism in Europe: Country Analyses, Counter-strategies and Labor-market Oriented Exit Strategies (pp. 133-156). Berlin, Germany: Friedrich-Ebert-Stiftung.

Mazzoleni, G. (2003). The media and the growth of neo-populism in contemporary democracies. In G. Mazzoleni, J. Stewart, \& B. Horsfield (Eds.), The Media and Neo-populism. A Contemporary Comparative Analysis (pp. 1-20). Westport: Praeger.

Mazzoleni, G. (2014). Mediatization and political populism. In F. Esser \& J. Strömbäck (Eds.), Mediatization of Politics. Understanding the Transformation of Western Democracies (pp. 42-56). Basingstoke: Palgrave Macmillan.

Mesquita, M. (1994). O universo dos media entre 1974 e 1986. In A. Reis (Ed.), Portugal, 20 Anos de democracia (pp. 360-396). Lisboa: Círculo de Leitores.

Mesquita, M. (2003). O quarto equínoco. O poder dos media na sociedade contemporanea [The Fourth Mistake. The Power of the Media in Contemporary Societies]. Coimbra: Edições MinervaCoimbra.

Mitchell, A., Simmons, K., Matsa, K. E., \& Silver, L. (2018). Publics globally want unbiased News coverage, but are divided on whether their news media deliver. Pew Research Center. Retrieved from http://assets.pewresearch.org/wp-content/uploads/sites/2/2018/01/09131309/Publics-Globally-WantUnbiased-News-Coverage-but-Are-Divided-on-Whether-Their-News-MediaDeliver_Full-Report-and-Topline-UPDATED.pdf. 
Moffitt, B. (2016). The Global Rise of Populism: Performance, Political Style, and Representation. Stanford, CA: Stanford University Press.

Mudde, C. (2004). The populist zeitgeist. Government \& Opposition, 39(4), 541-563.

Newman, N., Fletcher, R., Levy, D., \& Nielsen, R. (2016). Reuters Institute Digital News Report 2016. Retrieved from https://reutersinstitute.politics. ox.ac.uk/sites/default/files/Digital-News-Report-2016.pdf.

Patterson, T. E. (1993). Out of Order. New York: Vintage.

Salgado, S. (2007). Os Veiculos da Mensagem Politica. Estudo de uma campanha eleitoral nos media [The Vehicles of Political Communication. Studying an Electoral Campaign in the Media]. Lisboa: Livros Horizonte.

Salgado, S. (2009). Os media e as eleições em Portugal: estudo da cobertura noticiosa das legislativas de 2005 e das presidenciais de 2006 [Media and elections in Portugal: Studying the news coverage of the 2005 legislative election and of the 2006 presidential election]. In M. C. Lobo \& P. Magalhães (Eds.), Legislativas 2005 e Presidenciais 2006 (pp. 39-74). Lisboa: Imprensa de Ciências Sociais.

Salgado, S. (2010). Os Candidatos Presidenciais: Construção de Imagens e Discursos nos Media [Presidential Candidates: Construction of Images and Discourses in the Media]. Coimbra: Edições MinervaCoimbra.

Salgado, S. (2014). The media of political communication. In C. Reinemann (Ed.), Political Communication Volume of the Handbook of Communication Sciences (HOCS) (pp. 269-288). Berlin: De Gruyter Mouton.

Salgado, S. (2018a). O factor "media" e as estratégias de construção de imagem dos candidatos presidenciais. In A. Costa Pinto \& P. Canelas Rapaz (Eds.), Presidentes e (Semi) Presidencialismo nas Democracias Contemporâneas (pp. 279-300). Lisboa: Imprensa de Ciências Sociais.

Salgado, S. (2018b). Where's populism? Online media and the diffusion of populist discourses and styles in Portugal. European Political Science. https://doi. org/10.1057/s41304-017-0137-4.

Salgado, S., \& Strömbäck, J. (2012). Interpretive journalism: A review of concepts, operationalizations and key findings. Journalism, 13(2), 144-161.

Salgado, S., Strömbäck, J., Aalberg, T., \& Esser, F. (2017). Interpretive journalism. In C. de Vreese, F. Esser, \& D. Hopmann (Eds.), Comparing Political Journalism (pp. 50-70). London and New York: Routledge and Taylor and Francis.

Taggart, P. (2000). Populism. Buckingham and Philadelphia: Open University Press.

Taggart, P. (2004). Populism and representative politics in contemporary Europe. Journal of Political Ideologies, 9(3), 269-288. 
Open Access This chapter is licensed under the terms of the Creative Commons Attribution 4.0 International License (http://creativecommons.org/licenses/ by $/ 4.0 /$ ), which permits use, sharing, adaptation, distribution and reproduction in any medium or format, as long as you give appropriate credit to the original author(s) and the source, provide a link to the Creative Commons license and indicate if changes were made.

The images or other third party material in this chapter are included in the chapter's Creative Commons license, unless indicated otherwise in a credit line to the material. If material is not included in the chapter's Creative Commons license and your intended use is not permitted by statutory regulation or exceeds the permitted use, you will need to obtain permission directly from the copyright holder. 